\title{
THE PRESENCE OF METASTASES IN REGIONAL LYMPH NODES IS ASSOCIATED WITH TUMOR SIZE AND DEPTH OF INVASION IN SPORADIC GASTRIC ADENOCARCINOMA
}

\author{
A presença de metástases em linfonodos regionais está associada ao tamanho tumoral e profundidade de invasão \\ no adenocarcinoma gástrico esporádico
}

\author{
Eduardo CAMBRUZZI ${ }^{1}$, Andreza Mariane de AZEREDO ${ }^{2}$, Ardala KRONHART ${ }^{2}$, \\ Katia Martins FOLTZ², Cláudio Galeano ZETTLER ${ }^{3}$, Karla Lais PÊGAS ${ }^{3}$
}

From the Hospital Conceição de Porto Alegre (Porto Alegre Conceição Hospital), Porto Alegre, RS, Brazil.

HEADINGS - Adenocarcinoma. Pathology. Stomach diseases. Prognosis.
ABSTRACT - Background: Gastric adenocarcinoma is more often found in men over 50 years in the form of an antral lesion. The tumor has heterogeneous histopathologic features and a poor prognosis (median survival of $15 \%$ in five years). Aim: To estimate the relationship between the presence of nodal metastasis and other prognostic factors in sporadic gastric adenocarcinoma. Method: Were evaluated 164 consecutive cases of gastric adenocarcinoma previously undergone gastrectomy (partial or total), without clinical evidence of distant metastasis, and determined the following variables: topography of the lesion, tumor size, Borrmann macroscopic configuration, histological grade, early or advanced lesions, Lauren histological subtype, presence of signet ring cell, degree of invasion, perigastric lymph node status, angiolymphatic/perineural invasion, and staging. Results: Were found 21 early lesions (12.8\%) and 143 advanced lesions (87.2\%), with a predominance of lesions classified as T3 ( $n=99 / 60,4 \%)$ and N1 $(n=62 / 37,8 \%)$. The nodal status was associated with depth of invasion $(p<0.001)$ and tumor size $(p<0.001)$. The staging was related to age $(p=0.048)$, histological grade $(p=0.003)$, and presence of signet ring cells $(p=0.007)$, angiolymphatic invasion ( $p=0.001)$, and perineural invasion $(p=0.003)$. Conclusion: In gastric cancer, lymph node involvement, tumor size and depth of invasion are histopathological data associated with the pattern of growth/ tumor spread, suggesting that a wide dissection of perigastric lymph nodes is a fundamental step in the surgical treatment of these patients.

\section{Correspondence:}

Eduardo Cambruzzi

E-mail: dudacambruzzi@yahoo.com.br

Fonte de financiamento: não há Conflito de interesses: não há

Recebido para publicação: 09/07/2013 Aceito para publicação: 18/10/2013

\section{DESCRITORES - Adenocarcinoma.} Patologia. Gastropatias. Prognóstico.
RESUMO - Racional: O adenocarcinoma gástrico é encontrado mais frequentemente em homens acima de 50 anos sob a forma de lesão antral. A neoplasia apresenta características histopatológicas heterogêneas e prognóstico ruim (sobrevida média de 15\% em cinco anos). Objetivo: Estimar a relação entre a presença de metástases nodais e demais fatores prognósticos no adenocarcinoma gástrico esporádico. Método: Foram avaliados 164 casos consecutivos de adenocarcinoma gástrico previamente submetidos à gastrectomia (parcial ou total), sem evidências clínicas de metástase à distância, sendo determinadas as seguintes variáveis: topografia da lesão, tamanho tumoral, configuração macroscópica segundo Borrmann, grau histológico, lesão precoce ou avançada, subtipo histológico segundo Lauren, presença de células em anel de sinete, grau de invasão, status dos linfonodos perigástricos, invasão angiolinfática/perineural e estadiamento. Resultados: Foram encontradas 21 lesões precoces (12,8\%) e 143 avançadas (87,2\%) com predomínio de lesões T3 (n=99/60,4\%) e N1 (n=62/37,8\%). O status nodal esteve associado à profundidade de invasão $(p<0,001)$ e tamanho tumoral $(p<0,001)$. O estadiamento esteve relacionado à idade $(p=0,048)$, grau histológico $(p=0,003)$ e presença de células em anel de sinete $(p=0,007)$, invasão angiolinfática $(p=0,001)$ e invasão perineural $(p=0,003)$. Conclusão: No adenocarcinoma gástrico, 0 envolvimento linfonodal, o tamanho tumoral e a profundidade de invasão são dados histopatológicos associados ao padrão de crescimento/disseminação neoplásico, sugerindo que a dissecção ampla de linfonodos perigástricos seja etapa fundamental no tratamento cirúrgico destes pacientes. 
INTRODUCTION

Gastric cancers are a heterogeneous group of neoplasms, which basically correspond to adenocarcinoma. Gastric cancer mainly affects individuals over 50 years of age, and incidence rates of the disease in males are approximately twice as high as for females. In general, individuals who develop gastric cancer concentrate in the lower economic strata. Risk factors include infection by Helicobacter pylori, loss of E-cadherin expression, p53 gene mutation, overexpression of cyclin D1 and EGFR, and consumption of food containing nitrous compounds. Adenocarcinoma may compromise different regions of the stomach, as well as present different macroscopic forms and histological patterns $s^{1,2,5,6,17}$. Lauren initially described that stomach cancer occurred in two main types, which differed in structure and behavior: intestinal type and diffuse type. The intestinal-type stomach cancer consists of glands similar to those of the intestine and it affects mostly the antrum. It corresponds to the type that most often develops vascular invasion and liver metastases. The diffuse-type stomach cancer is formed by poorly cohesive malignant cells within desmoplastic stroma. It more often affects the stomach body and it is prone to peritoneal spread ${ }^{7}$. To distinguish between both types seems to be relevant for tumor prognosis ${ }^{1,2,5,6,12,17}$.

The prognosis is poor, with a mean of only $10-15 \%$ of survival at five years, even in patients who previously had curative gastrectomy. Independent prognostic factors seem not to be associated with tumor size and macroscopic configuration; adverse factors include patients over 70 years, proximal location, and lymphovascular invasion. Survival rate is higher for the intestinal type since these tumors occur in younger patients and are less advanced lesions. The strongest prognostic determinant is the pathological stage, which can be determined by the TNM system ${ }^{1,23,5,17,18,20}$.

In the present study, the authors evaluated 164 separate cases of gastric adenocarcinoma in order to determine the association between lymph node metastasis and different prognostic factors.

\section{METHOD}

Analytical, cross-sectional and retrospective study in which the authors analyzed 164 separate cases of gastric adenocarcinoma without clinical evidence of distant metastasis, comprising a study period of 120 months (January 2001 to December 2011). The study was approved by the ethics committee of the Grupo Hospitalar Conceição. The cases in the sample corresponded to surgical specimens from partial or total gastrectomy previously evaluated at the laboratory of pathology of the Hospital Conceição de Porto Alegre, in Porto Alegre, RS. All samples were initially fixed in 10\% formalin and embedded in paraffin. For diagnostic confirmation of adenocarcinoma following histopathological criteria established by the World Health Organization, 3- $\mu \mathrm{m}$ histological sections were performed for each sample which and then stained by $\mathrm{H} \& \mathrm{E}$. All cases were evaluated by two pathologists, either individually or jointly. All samples corresponding to stomach biopsy only, other histological types of primary and secondary stomach cancers, as well as the product of gastric resections due to non-neoplastic diseases were excluded. In each case, the following anatomopathological data were determined: lesion topography (cardia, fundus, body and antrum), tumor size in centimeters in the longest axis of the lesion, macroscopic configuration of advanced lesions according Borrmann's classification ${ }^{1,3}$, differentiation degree (poorly differentiated, moderately differentiated, and well-differentiated), early or advanced lesion, histological subtype according to Lauren's classification (intestinal, diffuse, or mixed), degree of invasion (mucosa, submucosa, muscular, serosa) and spread to adjacent organs, presence signet-ring cells, presence of perineural and lymphovascular invasion, presence of metastases in perigastric lymph nodes, staging according to the TNM classification.

Statistical analysis was performed using tables and descriptive variables (mean and standard deviation). In order to verify the association between the presence of metastasis and the other variables, chi-square and Fisher's exact tests were used. To compare age and tumor size in cases with and without metastasis, Student's t-test for independent samples was used. Results were considered significant at a level of maximum significance of $5 \%$. SPSS statistical software version 10.0 was used was used for processing and analysis.

\section{RESULTS}

The mean age among the 164 cases in the sample was of 66.69 years $( \pm 8.568)$, with a prevalence of malignancy in males $(n=111 / 67,68 \%)$. Mean tumor size was $6.45 \mathrm{~cm}( \pm 3.228)$, with a mean of 13.6 lymph nodes isolated in each specimen. Twenty-one early lesions (12.8\%) and 143 advanced lesions (87.2\%) were found, with a prevalence of lesions ranked as T3 $(n=99 / 60,4 \%)$ and N1 ( $n=62 / 37,8 \%)$. The nodal status was associated with the depth of invasion $(p<0.001)$ and tumor size $(p<0.001)$. The mean tumor size among cases showing metastases in lymph nodes was $7.2 \mathrm{~cm}$, while among cases lacking metastases it was $4.6 \mathrm{~cm}$. The staging was related to age $(p=0.048)$, histological grade $(p=0.003)$, and presence of signet-ring cells $(p=0.007)$, lymphovascular invasion $(p=0.001)$, and perineural invasion $(p=0.003)$. Table 1 shows these findings. 
TABLE 1 - Association between the variables analyzed.

\begin{tabular}{|c|c|c|c|c|}
\hline & & $n-\%$ & $\begin{array}{c}\text { Nodal } \\
\text { status (p) }\end{array}$ & $\begin{array}{l}\text { Pathological } \\
\text { staging (p) }\end{array}$ \\
\hline & Well & $18-10.98 \%$ & & \\
\hline Differentiation level & Moderately & $68-41.46 \%$ & & \\
\hline & Poorly & $78-47.56 \%$ & 0.269 & 0.003 \\
\hline & Diffuse & $54-32.90 \%$ & & \\
\hline $\begin{array}{l}\text { Laurens nistological } \\
\text { classification }\end{array}$ & Intestinal & $99-60.40 \%$ & & \\
\hline & Mixed & $11-6.70 \%$ & 0.193 & --- \\
\hline & $\leq 3.0 \mathrm{~cm}$ & $23-14.02 \%$ & & \\
\hline Tumor size & $3.1-4.9 \mathrm{~cm}$ & $49-29.88 \%$ & O 001 & $-\pi+3$ \\
\hline & $\geq 5.0 \mathrm{~cm}$ & $92-56.10 \%$ & 0.001 & $\cdots$ \\
\hline Borrmann's & I & $20-13.98 \%$ & & \\
\hline macroscopic & II & $35-24.47 \%$ & & \\
\hline conformation - & III & $77-53.86 \%$ & & --- \\
\hline advanced lesions & IV & $11-7.69 \%$ & & \\
\hline & Cardia & $10-6,09 \%$ & & \\
\hline & Fundus & $4-2,45 \%$ & & \\
\hline lopography & Body & $58-35.37 \%$ & & --- \\
\hline & Antrum & $92-56.09 \%$ & & \\
\hline Presence of sic & t-ring cells & $52-31.7 \%$ & 0.592 & 0.007 \\
\hline $\begin{array}{r}\text { Presence of neoplas } \\
\text { inva }\end{array}$ & $\begin{array}{l}\text { lymphovascular } \\
\text { n }\end{array}$ & $113-68.9 \%$ & 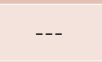 & 0.001 \\
\hline Presence of neoplast & erineural invasion & $53-32.32 \%$ & --- & 0.003 \\
\hline Surgical borders fr & from neoplasia & $137-83.54 \%$ & --- & --- \\
\hline & T1 & $21-12.80 \%$ & & \\
\hline & T2 & $20-12.19 \%$ & & \\
\hline & T3 & $100-60.98 \%$ & 0.001 & $\cdots$ \\
\hline & T4 & $23-14.02 \%$ & & \\
\hline TNM classification & NO & $51-31.10 \%$ & & \\
\hline IIVIVi Ciassilication & N1 & $62-37.80 \%$ & & \\
\hline & N2 & $32-19.51 \%$ & & --- \\
\hline & N3 & $19-11.58 \%$ & & \\
\hline & MO & $164-100 \%$ & & \\
\hline & M1 & $0-0 \%$ & & --- \\
\hline
\end{tabular}

\section{DISCUSSION}

INCA cites an estimated rate of 20,090 new cases of stomach cancer in 2012, of which 12,670 cases in males and 7,420 in females, representing the fifth highest incidence of malignant tumors in Brazil7. Adenocarcinoma accounts for about $95 \%$ of stomach malignant neoplasms, and global estimates suggest that this tumoral process is the fourth most common form of cancer and the second most common cause of death by cancer in the world. The incidence of this neoplasia varies considerably, being particularly high in many countries, most often affecting the lower socioeconomic groups and showing a male/female ratio of approximately 2:1. Infection by Helicobacter pylori, especially since childhood, family history of gastric cancer, low socioeconomic status, endogenous production of nitrosamines, high intake of nitroso and irritant compounds, and low consumption of fruits and vegetables are the primary risk factors associated with the development of gastric cancer. In addition to these factors, mutations in the p53 protein, changes in the E-cadherin expression, and potential progression of atrophic gastritis cases also seem to favor the malignant transformation of the gastric mucosa. The survival rate in five years for this cancer is approximately $22 \%$ with an estimated length of survival of about 15 months. Factors that influence survival are tumor size, depth of invasion of the serosa, presence of regional and distant lymph node metastasis, and stage of the disease $2,3,5,8,9,13,17,18,22$.

Moghimi-Dehkordi et al evaluated 746 patients with gastric cancer and found 530 cases in males (mean age of 60.5 years) and 216 cases in females (mean age of 57.5 years $)^{16}$. Santoro et al. divided 603 gastric cancer patients into two groups: one with ages of $<45$ years, and the other with ages of 46-75 years. In the younger group, 53\% were females, $73 \%$ had Lauren's diffuse pattern, 59\% were classified as N2-3, and $49 \%$ of the patients were in clinical stage IV. Survival rate was similar in both groups ( $32 \%$ between $5-10$ years) ${ }^{19}$. Bando et al suggest that the age is a better prognostic marker than nodal status in patients with early gastric cancer. Of the 4321 individuals analyzed, overall survival rate was $90.2 \%$; however, for both sexes, those who were older than 80 years showed a survival of $<30 \%^{2}$. Kim et al. reported that age over 60 years was the only significant prognostic factor in patients with early gastric cancer, whereas the prognosis of those with advanced gastric cancer was associated with lymphovascular neoplastic invasion and degree of invasion ${ }^{10}$.

Gastric adenocarcinoma most often affects the antrum (50-60\% of cases), and patients with early gastric cancer have an average five-year survival estimated at $90-95 \%$; in advanced lesions, this rate is approximately $15^{1,4,8,9,14,17,18}$. Shiraishi et al. evaluated a group of 95 patients with gastric adenocarcinoma with a diameter of $>10 \mathrm{~cm}$, and they found a median survival rate of 15 months. In this group of patients, the presence of regional lymph node metastasis, liver metastasis, and serosa invasion were significantly associated with the prognosis of neoplasia ${ }^{20}$. In a study conducted with 591 patients with gastric cancer, Liu et al. found that prognosis was associated with the degree of invasion and the presence of metastasis in regional lymph nodes, with no association with the tumor size ${ }^{15}$. Wang et al. determined a good prognosis for tumors measuring $<2.5 \mathrm{~cm}^{24}$.

The presence of regional lymph node metastasis, depth of invasion and differentiation degree are considered the most important associated prognostic factors $3,8,9,10,11,17,18,21,25$. The results of this study show that there was no significant statistical relationship between nodal status and histological grade $(p=0.269)$, presence of signet-ring cells $(p=0.592)$, and Lauren's histological pattern $(p=0.793)$, but with depth of invasion $(p=0.001)$. The presence of regional lymph node metastasis was found in $>50 \%$ of gastrectomy specimens, probably because they were mostly asymptomatic cancers up to advanced stages of the disease. Lauren's intestinal, diffuse, and mixed subtypes seem to have different pathogenetic basis. The intestinal subtype predominates in high-risk areas and seems to develop from precursor lesions, while the incidence of the diffuse subtype is relatively constant and has no identifiable precursor lesions. The intestinal subtype has an average age of onset of 55 years and a male/ female ratio of 2:1. The diffuse gastric cancer occurs in younger patients (mean age 48 years) and has a similar prevalence between males and females $3,8,9,11,13,14,17,18$. In a study of 289 gastrectomy specimens, Lemes et al. 
reported the presence of Lauren's intestinal subtype in 178 samples (62\%), with prevalence of these lesions in males $(n=116)$, and of Borrmann I or II types. In this group, 230 specimens corresponded to advanced gastric cancer ${ }^{13}$.

According to Liu et al., the presence of lymphovascular neoplastic invasion is an important prognostic factor for gastric cancers that show no lymph node metastasis. Among the 188 patients studied by this author, 158 patients were ranked stage T1NOMO and 30 patients were ranked stage T1N1M0, with survival rate being lower in cases where lymphatic invasion was detected ${ }^{15}$. According to Chi et al., 85 patients with stage-T3 gastric cancer and tumor measuring $>8$ $\mathrm{cm}$ had a survival rate of $33.8 \%$ in five years ${ }^{4}$. An et al. found a five-year survival rate of $26.7 \%$ for cases of Borrmann's stage IV gastric adenocarcinoma, and $>61.2 \%$ for the stages I, II and III ${ }^{1}$.

\section{CONCLUSION}

The presence of metastases in perigastric lymph nodes was associated with depth of invasion and tumor size, while the pathological stage was associated with age and histological grade. Thus, early detection of gastric cancer and extensive resection of perigastric tissues are key factors in treating and improving the survival rate of patients with this malignancy.

\section{REFERENCES}

1. An J, Kang TH, Choi MG et al. Borrmann Type IV: An Independent Prognostic Factor for Survival in Gastric Cancer. J Gastrointest Surg 2008, 12 (8): 1364-1369.

2. Bando E, Kojima N, Kawamura T et al. Prognostic value of age and sex in early gastric cancer. Br J Surg 2004, 91(9): 1197-1201.

3. Carneiro $F$, Sobrinho-Simões M. Metastatic pattern of gastric carcinoma. Hum Pathol 1996, 27: 213-214.

4. Chi Z, Huang CM, Zheng $\mathrm{CH}$ et al. Prognostic significance of tumor size in T3 gastric cancer. Chin J Gastroint Surg 2011, 12 (2): 114-6.

5. Crew KD, Neugut AI. Epidemiology of gastric cancer. World J Gastroenterol 2006, 12 (3): 354-62.

6. He MM, Zhang DS, Wang F et al. The role of non-curative surgery in incurable, asymptomatic advanced gastric cancer. PLos One 2013, 8 (12): e83921.
7. Instituto Nacional de Câncer - INCA. Estimativa 2012: incidência de câncer no Brasil. http://www.inca.gov.br/estimativa/2012/. Acessado em 22 de julho de 2012.

8. Ishigami $S$, Natsugoe $S$, Miyazono $F$ et al. Clinical merit of subdividing gastric cancer according to invasion of the muscularis propria. Hepatogastroenterology 2004, 51: 869-871.

9. Kappas AM, Fatouros M, Roukos DH. Is it time to change surgical strategy for gastric cancer in the United States? Ann Surg Oncol 2004, 11: 727-730.

10. Kim B, Cho SW, Min SK et al. Differences in prognostic factors between early and advanced gastric cancer. Hepatogastroenterology 2011, 58: 1032-1040.

11. Komuro A, Yashiro M, Iwata C et al. Diffuse-type gastric carcinoma: progression, angiogenesis, and transforming growth factor beta signaling. J Natl Cancer Inst 2009, 15: 592-604.

12. Laurén $P$. The two histological main types of gastric carcinoma: diffuse and so-called intestinal-type carcinoma. An attempt at a histo-clinical classification. Acta Pathol Microbiol Scand, 64: 31-49, 1965.

13. Lemes LAO, Neunschwander LC, Matta LAC et al. Carcinoma gástrico: análise sistemática de 289 gastrectomias consecutivas em Belo Horizonte (MG). JBPML, 39 (1): 57-65, 2003.

14. Liu C, Zhang R, Lu $Y$ et al. Prognostic role of lymphatic vessel invasion in early gastric cancer: a retrospective study of 188 cases. Surg Oncol 2010, 19 (1): 4-10.

15. Liu $Y$, Chen $X H$, Meng $X H$ et al. Multivariate prognostic study on node-positive gastric cancer: is tumor size a prognostic indicator? Hepatogastroenterology 2012, 59(114): 623-626.

16. Moghimi-Dehkordi B, Safaee A, Zali MR. Survival rates and prognosis of gastric cancer using an actuarial life-table method. Asian Pacific J Cancer Prev 2008, 9: 317-22.

17. Mori M, Sakaguchi $H$, Akazawa $K$ et al. Correlation between metastatic site, histological type, and serum tumor markers of gastric carcinoma. Hum Pathol 1995, 26: 504-508, 1995.

18. Roder JD, Bottcher K, Busch R et al. Classification of regional lymph node metastasis from gastric carcinoma. German Gastric Cancer Study Group. Cancer 1998, 82: 621-631.

19. Santoro R, Carboni F, Lepiane P et al. Clinicopathological features and prognosis of gastric cancer in young European adults. $\mathrm{Br} J$ Surg 2007, 94(6): 737-42.

20. Shiraishi N, sato K, Yasuda K et al. Multivariate prognostic study on large gastric cancer. J Surg Oncol 2007, 96(1): 8-14.

21. Talamonti MS, Kim SP, Yao KA et al. Surgical outcomes of patients with gastric carcinoma: the importance of primary tumor location and microvessel invasion. Surgery 2003, 134 (4): 720-727.

22. Takaishi S, Okumura T, Wang TC. Gastric Cancer Stem Cells. J Clin Oncol 2010, 26 (17): 2876-2882.

23. Wang $\mathrm{HM}$, Huang $\mathrm{CM}$, Zheng $\mathrm{CH}$ et al. Tumor size as a prognbostic factor in patients with advanced gastric cancer in the lower third of the stomach. World J Gastroenterol, 2012, 18 (38): 5470-5475.

24. Wang W, Li YF, Sun XW et al. Prognosis of 980 patients with gastric cancer after resection. Chin J Cancer 2010, 29: 923-930.

25. Yin D, Li D, Sun Z et al. Clinicopathologic features and prognosis analysis of mucinous gastric carcinoma. Med Oncol 2012, 29 (2): 864-870, 2012. 